\title{
XPS study of the adsorption mechanisms of DNA onto polypyrrole particles
}

\author{
Bachir Saoudi, Noraldeen Jammul, Mohamed M. Chehimi * Anne-Sophie Jaubert, \\ Chakib Arkam and Michel Delamar \\ Interfaces, Traitements, Organisation et Dynamique des Systèmes (ITODYS), \\ Université Paris 7-Denis Diderot, associé au CNRS (UMR 7086), 1 rue Guy de la Brosse, \\ 75005 Paris, France
}

\begin{abstract}
DNA adsorption onto polypyrrole (PPy) powder particles has been monitored, ex situ, by X-ray photoelectron spectroscopy (XPS) technique. DNA adsorption isotherms were determined by the quantitative analysis of the XPS spectra, and by plotting the $\mathrm{X} / \mathrm{N}$ atomic ratios $(\mathrm{X}=\mathrm{C}, \mathrm{O}, \mathrm{Cl}, \mathrm{P}$ and $\mathrm{Na}$ ) versus DNA equilibrium concentration. All XPS isotherms are of high affinity type, showing high adsorption amounts at low DNA concentrations in the suspension. Moreover, inspection of the C1s peak structure of the PPy-DNA complex revealed that it gradually gets wider and less tailing as DNA adsorbs, clearly showing the DNA contribution to the peak enlargement. In addition, the changes observed in the $\mathrm{Cl} 2 \mathrm{p}$ structure bring a strong supporting evidence of anion-exchange mechanism that takes place at initial stages of the interaction. Actually, the polypyrrole backbone loses part of its residual chlorides as the first DNA fragments adsorb and neutralize the PPy positive charges at the interface. Moreover, at relatively high amounts of adsorbed DNA, the PPy surface becomes screened necessitating thus that sodium cations co-adsorb in order to compensate for the excess of DNA negative charges. As a consequence of such screening of the PPy surface, DNA adsorption results in a positive spectral shift of all peaks of approximately $2.0 \mathrm{eV}$, a value that leads to the conclusion that DNA partially covers the PPy.
\end{abstract}

Keywords: Polypyrrole, DNA, adsorption, ion exchange, XPS

\section{Introduction}

Polypyrrole (see Fig. 1) is one of the most studied inherently conducting polymers (ICPs) [1] because of its several interesting properties such as electroactivity [2], redox and acid-base chemistry [3], ionic exchange properties [4], metallic-like conductivity (up to $300 \mathrm{~S} \mathrm{~cm}^{-1}$ ) and relatively high surface free energy [5] and specific surface area [6] compared to conventional polymers. These attractive properties, together with the ease of chemical or electrochemical synthesis in aqueous media and its relative longterm stability, made it a suitable candidate for the fabrication of biosensors [2], controlled drug release systems [7], and adsorbents for proteins [8-12] or DNA [13-15].

Polypyrrole can readily be prepared electrochemically as thin films on various electrodes, or chemically as a black powder that consists of aggregates of microspheres in the 200-400 nm size (Fig. 2).

Because polypyrrole is infusible, several groups have suggested its preparation as composite materials or colloidal dispersions in order to improve its processability [16-21].

\footnotetext{
${ }^{*}$ Corresponding author: Dr M.M. Chehimi, ITODYS, Université Paris 7-Denis Diderot, 1 rue Guy de la Brosse, 75005 Paris, France. Tel.: +33 1 44276809; Fax: +33 1 44276814; E-mail: chehimi@ paris7.jussieu.fr.
} 


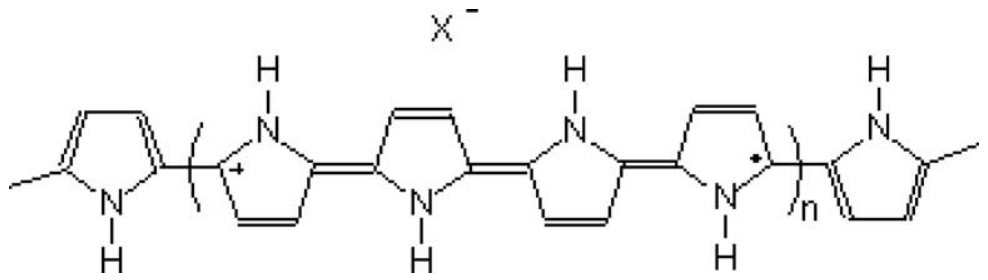

Fig. 1. Chemical structure of polypyrrole.

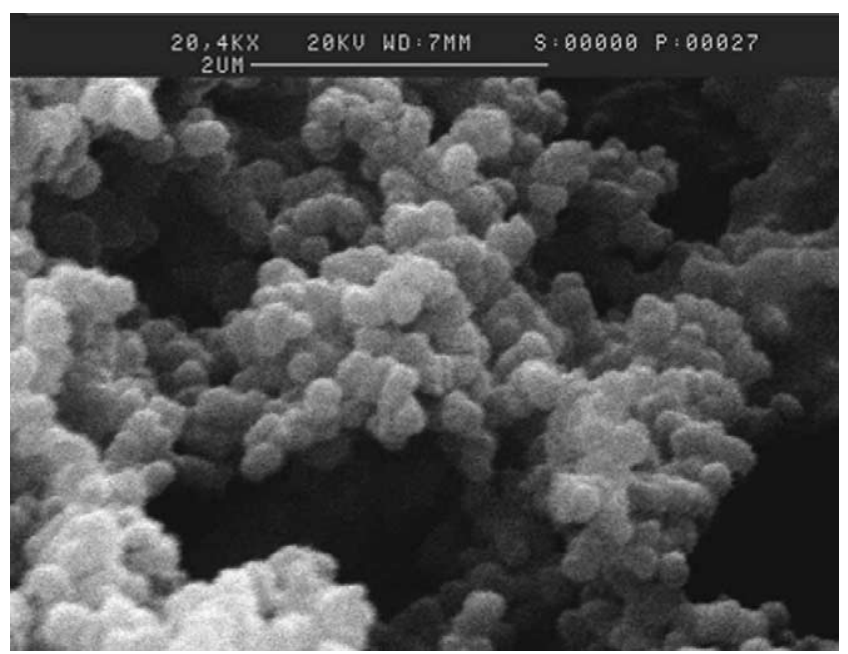

Fig. 2. SEM micrograph of a polypyrrole powder synthesized by oxidative polymerisation of pyrrole.

Though, colloidal dispersions of polypyrrole were initially proposed as processable forms of polypyrrole, it soon became clear that they could be deep black colored carriers of proteins [22,23] and DNA $[2,15]$ for visual agglutination tests and biochips, respectively. Particularly, calf thymus DNA fragments were adsorbed onto three polypyrrole-silica nanocomposite particles (untreated and amineor carboxylic acid-functionalised) at neutral $\mathrm{pH}$ in sodium phosphate buffer [15]. The extent of DNA adsorption was found to be $22 \mathrm{mg} / \mathrm{g}$ for the aminated PPy-silica particles and $6.5 \mathrm{mg} / \mathrm{g}$ for the carboxylated particles. The limited DNA adsorption onto the unfunctionalized PPy-silica particles was related to the low polypyrrole content at the outer particle surface as shown by XPS analysis, thus to a small quantity of positive charges on the substrate surface. This result is in line with a thorough study of DNA adsorption onto polypyrrole powders, which have positively charged polymer backbones [14]. In this regard, $\mathrm{PPyCl}, \mathrm{PPyNO}_{3}$ and $\mathrm{PPySO}_{4}$ were selected as model substrates for determining DNA adsorption isotherms. It was concluded that $\mathrm{pH}$, ionic strength and dopant nature affect the adsorptive capabilities of PPy towards DNA. In addition, high frequency impedance measurements performed on decanted polypyrrole and DNA-coated polypyrrole indicated a significant decrease in the dielectric parameters in $0.01 \mathrm{M}$ phosphate buffer at $\mathrm{pH} 7$ upon the adsorption, as a result of the coverage of the conductive PPy by an insulating layer of DNA, while maintaining however the mobility of doping anions in the bulk of the polymer [24]. Irreversibility of the adsorption process was assessed. DNA conformational changes on the adsorbing surface have been suspected to occur as time elapses and as functions of the amount of adsorbed DNA [24]. 
The previous studies aimed at determining adsorption isotherms by the depletion method using UVvisible spectroscopy. We wished to take advantage of the unique capabilities of XPS [25-28] to characterise in a direct manner the DNA adsorption onto polypyrrole powders. Various utilisations of XPS in biology were described by Millard [29,30], and by Paynter and Ratner [31]. Pioneering studies dealing with the different DNA bases were carried out by XPS [32,33], and allowed to measure the binding energies of the core electrons $\mathrm{C} 1 \mathrm{~s}$ and $\mathrm{N} 1 \mathrm{~s}$, and were found comparable with the theoretically calculated energies [34,35]. In biology, Klein and Cramer [36] highlighted the quantitative aspect of XPS technique by determining the composition of both nitrogen and sulphur of proteins of barley, corn, oat grains, starting from the line intensities of nitrogen and sulphur photoelectrons. Millard et al. [37] analyzed by XPS the chemical modifications in proteins (e.g., bovine serum albumin, BSA) and estimated the extent of such changes induced by chemical treatment on various functional groups. Up to now, XPS has seldom been applied to the analysis and study of adsorption of proteins, DNA (or ODN) and cells onto surfaces. Ratner et al. [38] studied the adsorption of haemoglobin protein on PTFE and platinum: they form a monolayer on platinum, and aggregates on PTFE. Leavitt et al. [39] studied the adsorption of a DNA fragment (7250 base pairs) on gold. The atomic sulphur grafted with phosphate of each nucleotide constitutes a bridging for DNA adsorption on such a surface. Their XPS results showed clearly that the phosphate and sulphur concentration between the two surfaces (gold and DNA) is significant, confirming the validity of their assumption of sulphur bridging.

XPS has recently been applied for the surface characterisation of DNA immobilised onto gold electrodes and showed the significant role of bases and phosphates in the interfacial interactions [40]. It has also been used to investigate the role of surface treatment of glass substrates on the immobilisation of human serum albumin, fibroblasts and granulocytes [41].

The present work aimed at contributing to a better understanding of the DNA adsorption onto surfaces. This topic is nowadays the centre of a very intense research activity. Such a research is undoubtedly of a great interest for the design of biomaterials and their biomedical applications. Particularly, one of the important issues in this field is the response that results from contact between the biomaterial and the biological system.

In the following, we report for the first time, a complete set of data dealing with an XPS analysis of a PPy-DNA interface. This study comprises original XPS survey spectra of DNA fibres together with that of carbon and nitrogen high-resolution peaks. Since DNA/PPy interaction is achieved in the presence of a buffer medium, and given the anion exchange properties of polypyrrole [4], it is important to examine thus the anion exchange process undergone by polypyrrole powders in the conditioning stage prior to DNA adsorption. Therefore, the paper is divided into two main sections: (i) study and quantification of the anion-exchange process of polypyrrole following its conditioning in buffered media; (ii) XPS characterization of DNA-coated polypyrrole in relation to three reference materials, namely uncoated polypyrrole powders, buffer-conditioned polypyrrole and DNA fibres.

\section{Experimental}

\subsection{Synthesis of polypyrrole}

Doubly-distilled pyrrole (Aldrich; $1.75 \mathrm{ml}, 0.025 \mathrm{~mol}$ ) was added to $c a .100 \mathrm{ml}$ of a stirred aqueous solution of $\mathrm{FeCl}_{3} \cdot 6 \mathrm{H}_{2} \mathrm{O}$ (Prolabo; $20.26 \mathrm{~g}, 0.075 \mathrm{~mol}$ ) or $\mathrm{Fe}\left(\mathrm{NO}_{3}\right)_{3} \cdot 9 \mathrm{H}_{2} \mathrm{O}$ (Prolabo; $30.30 \mathrm{~g}, 0.075 \mathrm{~mol}$ ), and urea (Aldrich; $1.5 \mathrm{~g}, 0.025 \mathrm{~mol}$ ). The solutions were stirred for $2 \mathrm{~h}$ at $0^{\circ} \mathrm{C}$ under a stream of nitrogen 
and the resulting black precipitate of chloride-doped polypyrrole ( $\mathrm{PPyCl})$ and nitrate-doped polypyrrole $\left(\mathrm{PPyNO}_{3}\right)$ powders were vacuum-filtered and washed with copious amounts of de-ionised water until the washings were clear. The powders were then dried in a desiccator overnight. The powders were sieved to $c a .100 \mu \mathrm{m}$ before adsorption experiments. The specific surface area, as determined by BET measurements, was 25.5 and $13.4 \mathrm{~m}^{2} / \mathrm{g}$ for $\mathrm{PPyCl}$ and $\mathrm{PPyNO}_{3}$, respectively. The compressed pellet conductivity was found to be $1.5 \mathrm{~S} / \mathrm{cm}$ for both types of polypyrrole powders.

\subsection{Buffers}

Sodium phosphate (Fluka) was used to prepare buffered solutions aqueous solutions at $\mathrm{pH} 7$ and $0.1 \mathrm{M}$ (unless otherwise indicated in the text); and Tris- $\mathrm{HCl}$ buffer, at $\mathrm{pH} 8$ and $0.1 \mathrm{M}$.

\subsection{Conditioning of polypyrrole powders in buffered medium}

$10 \mathrm{mg}$ of polypyrrole were inserted into a Pyrex tube containing $7 \mathrm{ml}$ of the phosphate buffer. This tube was then homogeneously stirred for 20 hours. After that, the tube was centrifuged and a volume of the supernatant was extracted to serve as a reference for differential UV monitoring.

\subsection{DNA adsorption}

\subsubsection{Preparation of DNA}

Calf thymus double-stranded DNA (highly polymerised salt from Sigma) was solubilized in $0.05 \mathrm{M}$ Tris- $\mathrm{HCl}$ buffer (Aldrich, $\mathrm{pH}$ 8.0) containing $0.01 \mathrm{M}$ ethylene diamine tetra-acetic acid (EDTA). The resulting solution was periodically sonicated in an ice bath for 30 seconds, followed by 'rest' periods of two minutes. This procedure was repeated ten times and resulted in DNA fragments in the size range of $400-3000$ base pairs (contour lengths $\sim 0.14-1.0 \mu \mathrm{m}$ ). The DNA was used without further purification; the contamination by proteins is less than $3 \%$. The $A_{260} / A_{280}$ ratio (ratio of the absorbances at 260 and $280 \mathrm{~nm}$, respectively) of the final preparation is 1.8 . It is to mention that the DNA supernatant of the DNA-adsorbent suspension had a $A_{260} / A_{280}$ ratio between 1.8-2. Standard calibration curves of UV absorbance (at $260 \mathrm{~nm}$ ) versus concentration were obtained for aqueous DNA solutions.

\subsubsection{Reference measurements for adsorption isotherms}

A fixed mass of powder was placed in a test tube and a precise volume of sodium phosphate buffer solution ( $\mathrm{pH} 7$ ) was added. This mixture was stirred using Speci-mix (Prolabo) device for 20 hours (duration long enough for the equilibrium to be attained). The resulting dispersion was then centrifuged and an aliquot of the supernatant was extracted to become a reference for UV spectroscopy (Varian DMS 200 spectrometer).

\subsubsection{Equilibrium DNA adsorption isotherms}

Into several Pyrex tubes, all containing the same suspension of polypyrrole/buffer $(7 \mathrm{ml})$, we separately added different volumes of DNA so as to obtain a final concentration of a few $\mu \mathrm{g} / \mathrm{ml}$ of DNA in solution. In addition to the quantity of nucleic acid added to the preceding tube, a fixed increment of DNA is added to a following tube so as to increase the adsorption of DNA. By using this experimental arrangement, we can plot what is called one-shot adsorption isotherms of DNA onto PPy; such isotherms will advantageously be compared to those obtained by the depletion method. The test tube is then agitated for $20 \mathrm{~h}$ (a period of time which was previously found to be sufficient for reaching equilibrium [14]). Subsequent centrifugation resulted in sedimentation of the DNA-coated PPy powder. The 
concentration of DNA in the supernatant was determined by UV spectroscopy. The amount of DNA adsorbed per mass unit of substrate, $b$, was calculated for each of these successive additions using the following equation:

$$
b=\left(A_{0}-A\right) \cdot v \cdot c / m,
$$

where $v$ is the total solution volume; $A_{0}$ is the absorbance of the total amount of added DNA; $A$ is the absorbance of the equilibrium DNA; $m$ is the mass of substrate and $c$ is a constant relating absorbance to DNA concentration (an absorbance of 1.00 , at $260 \mathrm{~nm}$, is equivalent to $50 \mu \mathrm{g}$ double-stranded DNA per $\mathrm{ml}$ ). Isotherms were obtained by plotting the amount of DNA adsorbed against the equilibrium concentration of DNA remaining in solution. The centrifuged DNA-coated polypyrrole powders were further washed to remove loosely bound DNA and dried thoroughly prior to XPS analyses.

\section{5. $X P S$}

XPS signals were recorded using a VG Scientific ESCALAB MKI system operated in the constant analyser energy mode. Al K $\alpha$ X-ray source was used at a power of $200 \mathrm{~W}(20 \mathrm{~mA} \times 10 \mathrm{kV})$ and the pass energy was set at $20 \mathrm{eV}$. Digital acquisition was achieved with a Cybernetix system (Marseille Luminy, France) and the data collected with a personal computer. Charge referencing was determined by setting the main $\mathrm{C} 1 \mathrm{~s}(\mathrm{C}-\mathrm{C} / \mathrm{C}-\mathrm{H})$ component at $285.0 \mathrm{eV}$. The surface composition (in atomic \%) of the various samples was determined by considering the integrated peak areas of C1s, N1s, O1s, Cl2p, S2p and P2p and their respective experimental sensitivity factors. The fractional concentration, $\% A$, of a particular element $\mathrm{A}$ is computed using:

$$
\% A=\left(I_{A} / s_{A}\right) / \sum\left(I_{n} / s_{n}\right) \times 100 \%,
$$

where $I_{n}$ and $s_{n}$ are the integrated peak areas and the sensitivity factors of the element $n$, respectively; $I_{A}$ and $s_{A}$ are those of the element $A$.

\subsection{Ion-exchange chromatography}

A Dionex anion-exchange chromatograph (SP Model) equipped with a conductivity detector (CDM2) and a suppressor (ASRS-I) was used. The column was an IonPac AS4A-SC (Dionex). The mobile phase was a mixture of $1.8 \mathrm{mM}$ sodium carbonate (Fluka) and $1.7 \mathrm{mM}$ sodium bicarbonate (Fluka) and the flow rate set at $1.1 \mathrm{ml} / \mathrm{min}$.

Anion concentrations in the test supernatants were determined using calibration curves obtained with standard aqueous solutions of $\mathrm{NaCl}, \mathrm{NaNO}_{3}$, and $\mathrm{Na}_{2} \mathrm{HPO}_{4}$ (all Prolabo products). Data acquisition and processing were performed using a JMBS Borwin software (Le Fontanil, France).

\section{Results and discussion}

In previous studies, we reported that polypyrrole powders were conditioned overnight prior to DNA adsorption isotherms. This timescale was long enough to allow polypyrrole to exchange the dopants from the outermost layers with the dopants from the buffered medium. Previously, we concluded based on XPS analysis of phosphate buffer-treated PPy powders (see also below) that chloride anions from PPyCl 
were exchanged with the phosphate anions from the buffer [24]. However, since XPS is a surface specific technique, the spectra cannot tell whether the bulk of the powder particles undergoes anion-exchange with the phosphate buffer. Ion-exchange chromatography is thus useful to determine the amount of dopants leached into the conditioning medium and thus the fraction of exchanged dopants.

Figure 3 presents ion-chromatograms of the buffer before and after incubation with $\mathrm{PPyCl}$ and $\mathrm{PPyNO}_{3}$. In Figs $3 \mathrm{~b}$ and $3 \mathrm{c}$, the presence of chloride and nitrate peaks on the chromatograms after incubation clearly show that PPy powders released ions into the buffer. In parallel, it is easy to demonstrate, using dilute buffer solutions, that a certain amount of phosphate anions was lost by the buffer, enabling us to conclude that PPy undergoes an ion exchange process with the solution: it loses its synthesis dopant and picks up phosphate anions to ensure its electroneutrality. Figure 4 shows the ion exchange capacity of polypyrrole (expressed in moles of dopants per gram of polypyrrole) versus the ionic strength. The capacity factor is found to be in the 0.8 to $2.8 \times 10^{-3} \mathrm{~mol} / \mathrm{g}$ range. This is a higher exchange factor than that of commercial ion exchange resins which is in the $5 \times 10^{-6}$ to $10^{-3} \mathrm{~mol} / \mathrm{g}$ range [42]. Ge and Wallace [4] obtained a value of $7.1 \times 10^{-4} \mathrm{~mol} / \mathrm{g}$ for $\mathrm{PPyCl}$ films. From the exchange factors and the bulk composition, the percentage of dopant from the bulk powders could be estimated.

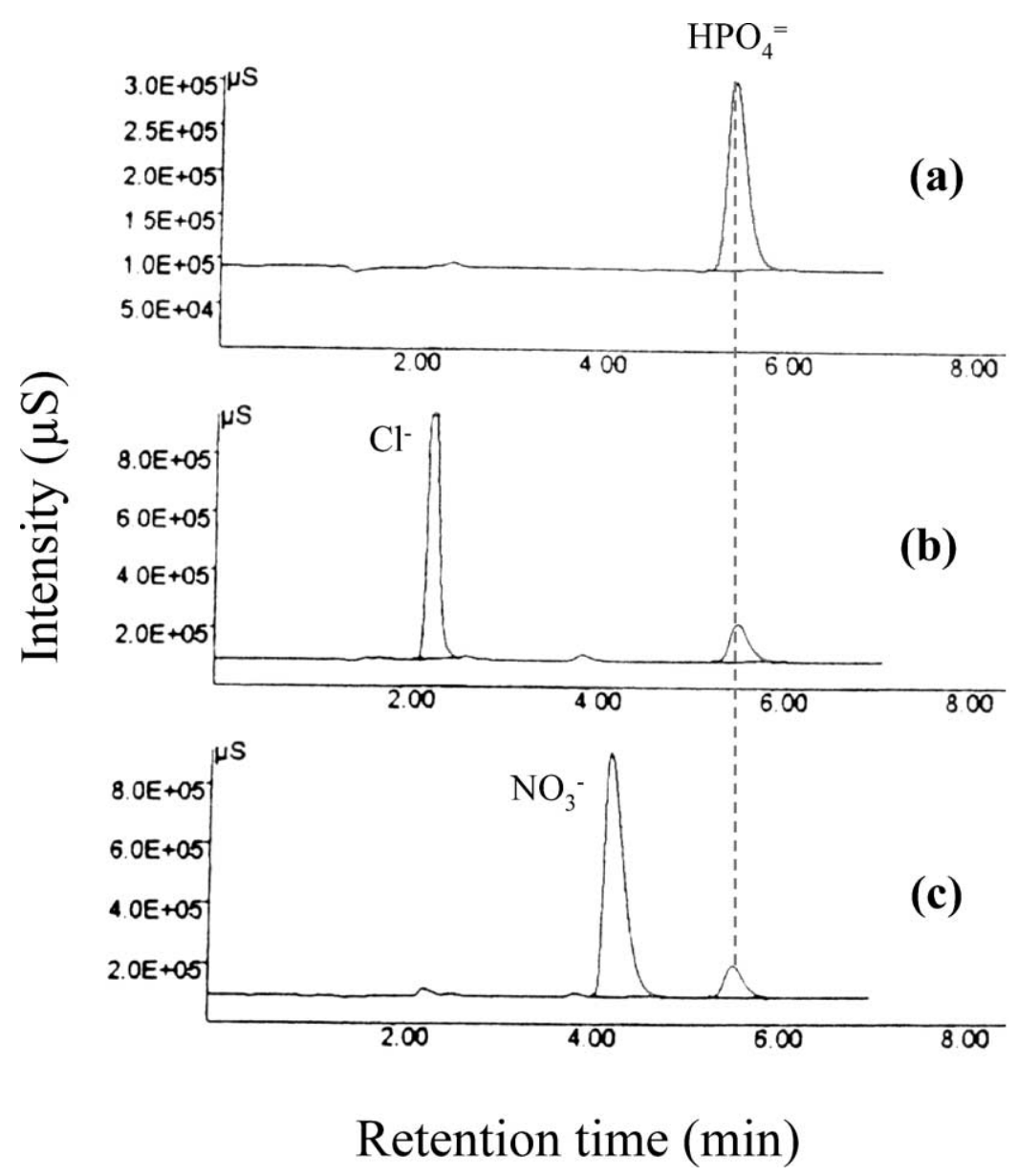

Fig. 3. Ion-exchange chromatograms of phosphate buffer before and after incubation with polypyrrole powders: (a) untreated buffer, (b) after incubation with $\mathrm{PPyCl}$, and (c) after incubation with $\mathrm{PPyNO}_{3}$. 


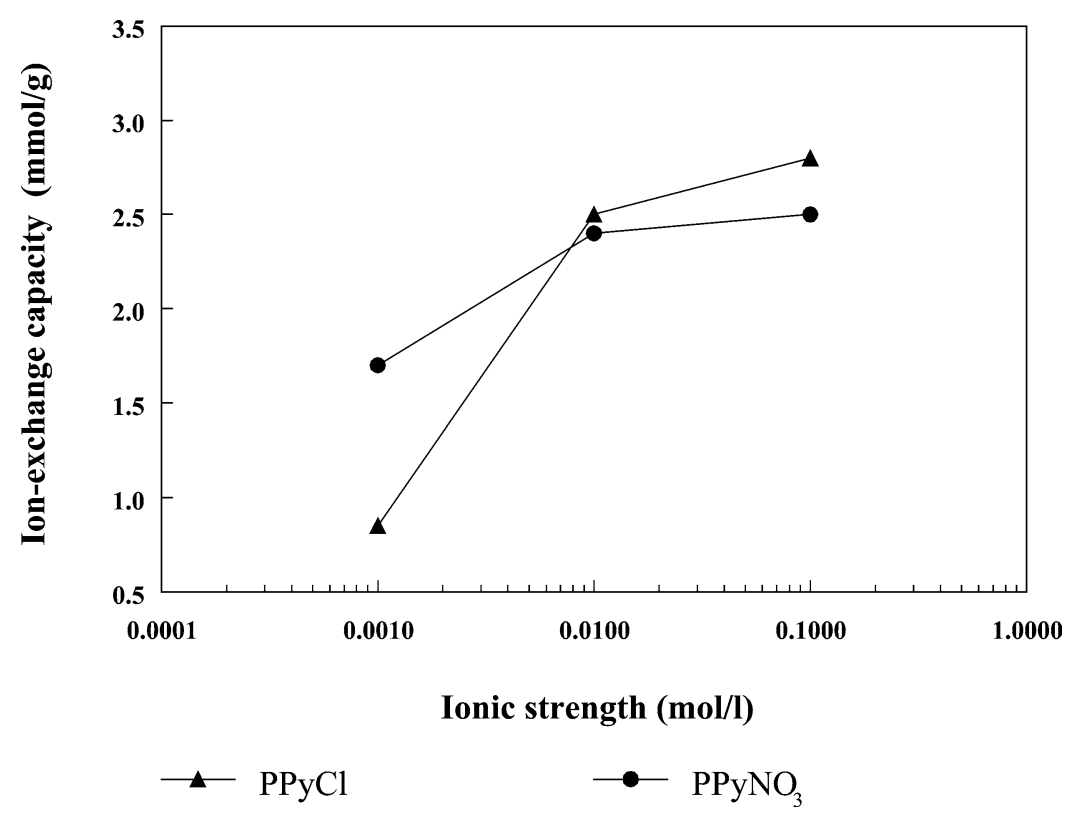

Fig. 4. Ion-exchange capacity of polypyrrole powders (in mol/g) versus the ionic strength at $\mathrm{pH} 7$.

Table 1

Fraction (in \%) of dopant exchanged by $\mathrm{PPyCl}$ and $\mathrm{PPyNO}_{3}$ with phosphates versus the ionic strength

\begin{tabular}{ccc}
\hline Ionic strength $(\mathrm{mol} / \mathrm{l})$ & $\mathrm{PPyCl}$ & $\mathrm{PPyNO}_{3}$ \\
\hline $10^{-3}$ & 29 & 54 \\
$10^{-2}$ & 83 & 77 \\
$10^{-1}$ & 93 & 79 \\
\hline
\end{tabular}

The results are reported in Table 1 which clearly indicates that the dopant exchange rate with the phosphate anions strongly increases as the ionic strength of the buffer increases in the $10^{-3}-10^{-2} \mathrm{M}$ interval. However, it seems to reach a saturation level at $10^{-2} \mathrm{M}$, suggesting that the exchange phenomena is a whole process even at high salt concentration. Indeed, there is a residual fraction in the bulk powder, in the $\sim 10-20 \%$ range approximatively. Particularly, in the case of $\mathrm{PPyNO}_{3}$, ion exchange saturates at $10^{-2} \mathrm{M}$ and the polymer no longer takes up the phosphates as the ionic strength increases.

In the following, although the polypyrrole powders undergo ion-exchange with the phosphates, we refer anyway to the former polymer before conditioning. Indeed, even if the dopant can be exchanged, it nevertheless irreversibly confers to the bulk polymer some properties such as its backbone chemical structure, end chains and surface defects. Therefore, the following abbreviation will be adopted:

$\mathrm{PPyCl}$ and $\mathrm{PPyNO}_{3}$ : refer to the freshly synthesized powders prior to conditioning in the buffer.

PPyCl-NaP and $\mathrm{PPyNO}_{3}-\mathrm{NaP}$ : sodium phosphate buffer-treated powders.

PPyCl-DNA and $\mathrm{PPyNO}_{3}-\mathrm{DNA}$ : conditioned polypyrrole powders coated with DNA.

Figure 5 shows survey spectra of $\mathrm{PPyCl}$, DNA fibres, PPyCl-NaP and PPyCl-DNA when the DNA adsorption reached $0.29 \mathrm{mg} / \mathrm{m}^{2}$. The peak Cl2p is almost absent from the surface of PPyCl-NaP and simultaneously one can notice the presence of phosphorus (detected by P2p peak) at PPyCl-NaP surface. These XPS findings parallel ion-exchange chromatograms, which show a depletion of the phosphate ions 

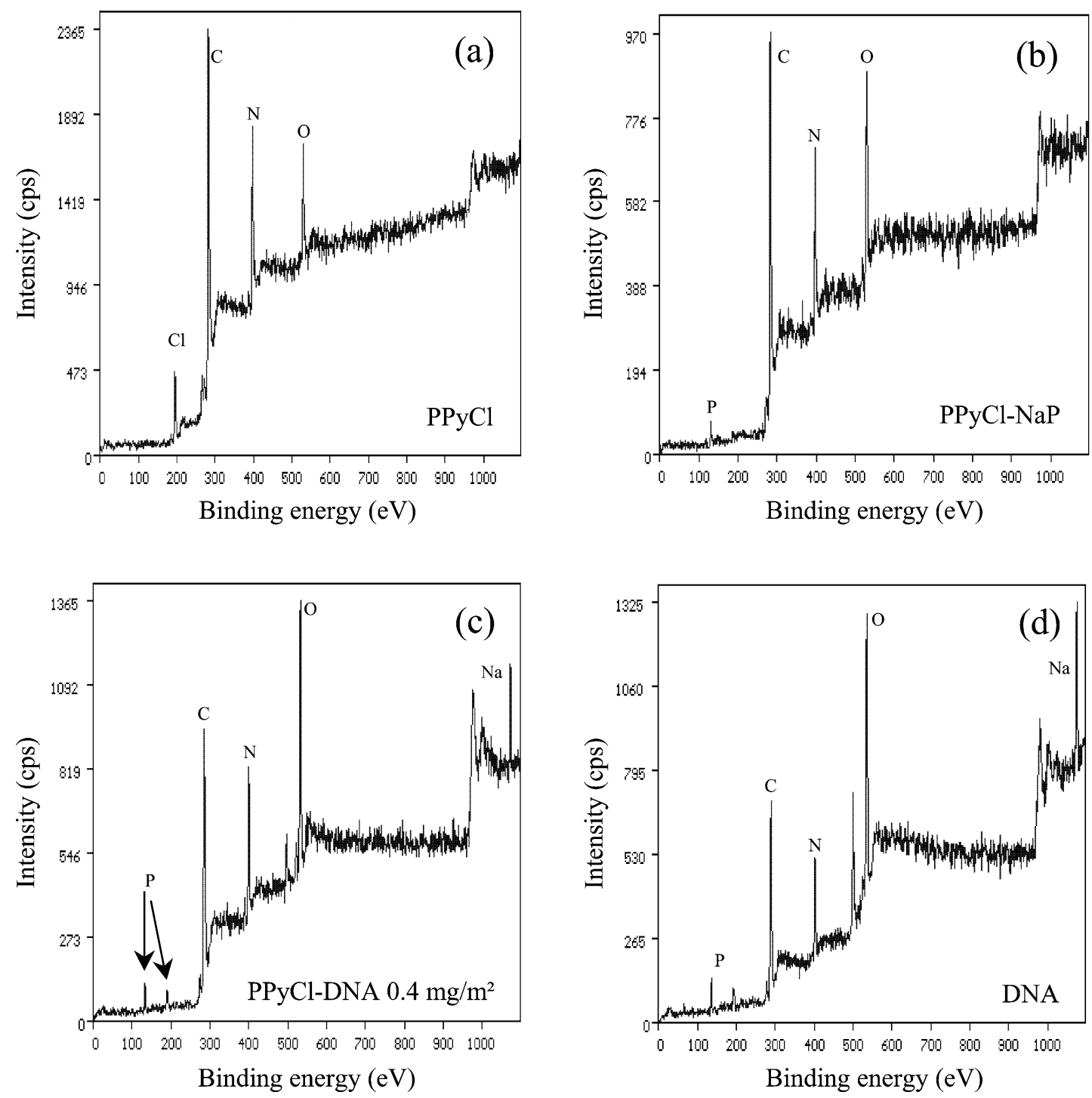

Fig. 5. XPS survey scans of (a) PPyCl bulk powder, (b) PPyCl-NaP, (c) PPy-DNA (0.4 mg/m²), (d) DNA fibres.

from and uptake of chloride species by the supernatant, following treatment of $\mathrm{PPyCl}$ bulk powder in the buffer solution.

The uptake of buffer phosphate anions by the conditioned $\mathrm{PPyCl}$ results in an increase of the relative intensity of O1s peak as well as in the appearance of a strong P2p signal. However, for the DNA-coated polypyrrole, the $\mathrm{O} 1 \mathrm{~s}$ and $\mathrm{P} 2 \mathrm{p}$ peaks show higher intensities relatively to the conditioned PPy due to the contribution of the DNA double helix. This is in line with the structure of the wide scan from pure DNA, displayed in Fig. 5d. One can easily distinguish the characteristic DNA composition elements, C, O, N, $\mathrm{P}$, and particularly sharp Na1s and NaKLL peaks since DNA is a sodium salt.

Figure 6 displays the $\mathrm{C} 1 \mathrm{~s}$ peaks from conditioned $\mathrm{PPyCl}$ before and after DNA adsorption, together with the $\mathrm{C} 1 \mathrm{~s}$ structure of DNA for comparison. On the one hand, polypyrrole exhibits a skewed and 

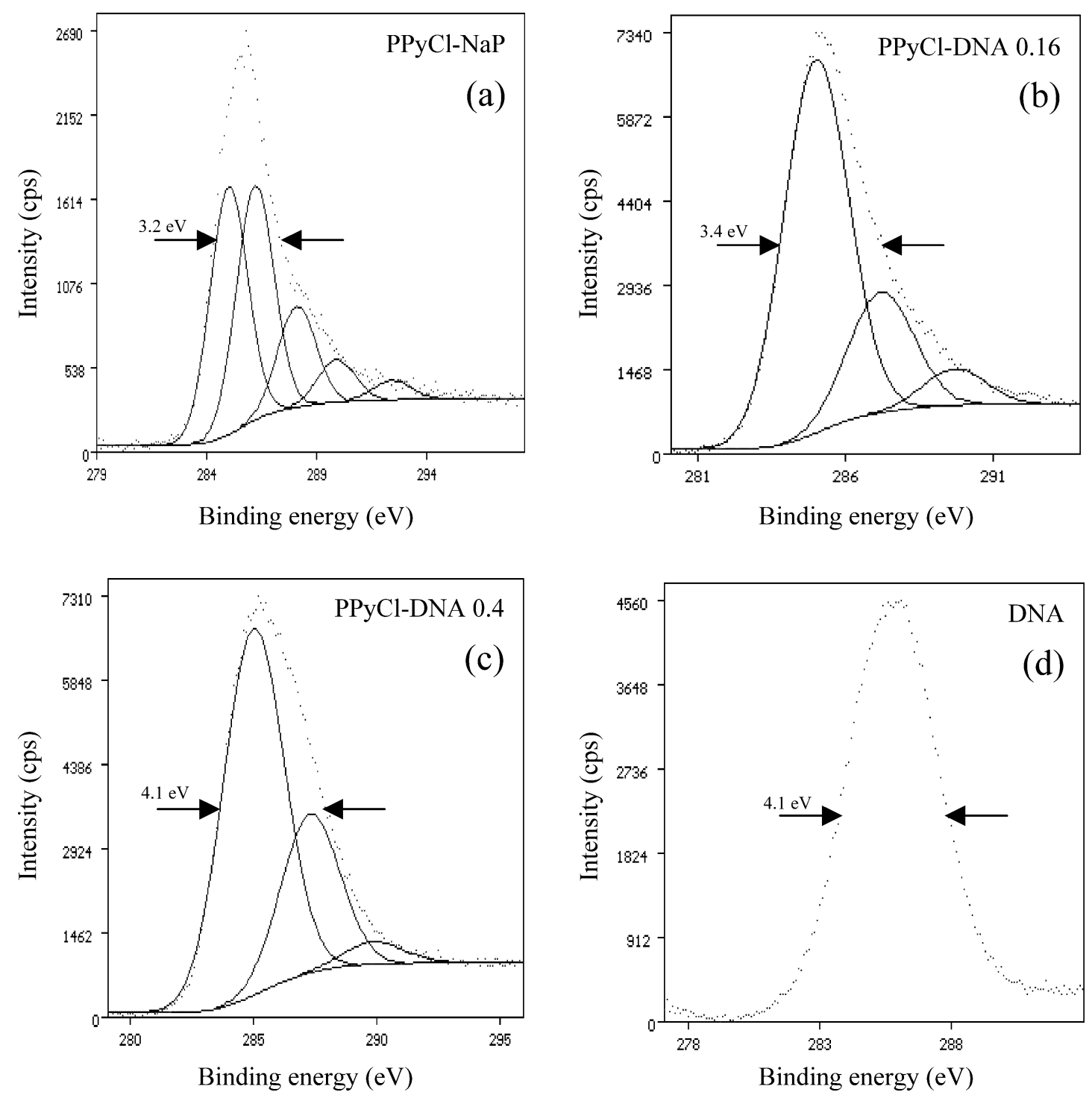

Fig. 6. High resolution C1s regions of (a) PPyCl-NaP, (b) PPy-DNA $\left(0.16 \mathrm{mg} / \mathrm{m}^{2}\right)$, (c) PPy-DNA $\left(0.4 \mathrm{mg} / \mathrm{m}^{2}\right)$, (d) DNA fibres.

tailing peaks with an apparent maximum around $285 \mathrm{eV}$. On the other hand, DNA exhibits an almost symmetrical $\mathrm{C} 1 \mathrm{~s}$ peak and this is due to the huge number of various functional groups contributing to the C1s peak (see Table 2). After DNA adsorption, the C1s structure tends to lose its tailing shape and becomes more and more symmetric. The various functional groups and their $\mathrm{C} 1 \mathrm{~s}$ chemical shifts are displayed in Table 2.

The N1s peak structures are displayed in Fig. 7 for PPyCl-NaP and PPyCl-DNA (after adsorption of $0.4 \mathrm{mg} / \mathrm{m}^{2}$ of DNA). The conditioned polypyrrole exhibits an N1s structure similar to that of bulk powder polypyrrole, with a main component centred at $\sim 400 \mathrm{eV}$ and minor components at low $(\sim 398.5 \mathrm{eV})$ and high $(401-402,402-403 \mathrm{eV})$ binding energies, which are assigned to imine defects $(\mathrm{C}=\mathrm{N})$ and positively charged nitrogen atoms, respectively. We have previously shown that acidic $\mathrm{pH}$ contributes up to $30 \%$ of 
Table 2

$\mathrm{C} 1 \mathrm{~s}$ chemical shifts for carbon in functional groups from the deoxyribose sugar and puric and pyrimidic bases in DNA

\begin{tabular}{lll}
\hline Functional groups & Chemical species & Binding energy $(\mathrm{eV})$ \\
\hline $\mathrm{CC} / \mathrm{CH}, \mathrm{C}-\mathrm{O}$ & Deoxyribose & $285 ; 286.5$ \\
$\mathrm{O}-\mathrm{C}-\mathrm{N}$ & Glycosidic bond & 287.8 \\
$\mathrm{CC} / \mathrm{CH} ; \mathrm{C}-\mathrm{N} ; \mathrm{N}-\mathrm{C}=\mathrm{C} ; \mathrm{N}-\mathrm{CO}-\mathrm{N}$ & Cytosine C & $285 ; 285.7 ; 287.8 ; 289$ \\
& Thymine T & $285 ; 285.7 ; 288 ; 289$ \\
$\mathrm{C}-\mathrm{N} ; \mathrm{N}-\mathrm{C}-\mathrm{N}, \mathrm{N}=\mathrm{C}-\mathrm{N}$ & Adenine A & $285.7 ; 286.5$ \\
& Guanine & $285 ; 286.5 ; 287.2$ \\
\hline
\end{tabular}

Data taken from [32,33].
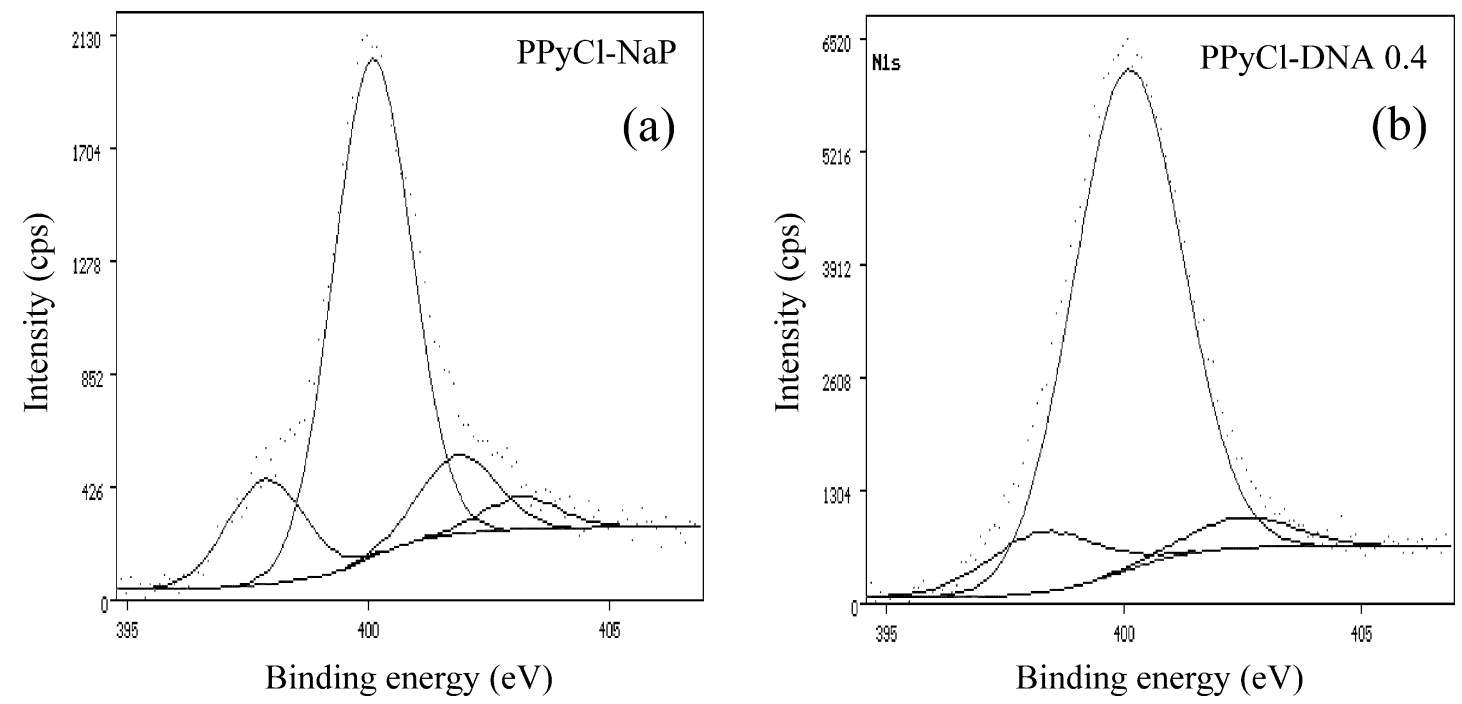

Fig. 7. High resolution N1s regions of (a) PPyCl-NaP, (b) PPy-DNA $\left(0.4 \mathrm{mg} / \mathrm{m}^{2}\right)$.

the positively charged nitrogen atoms, whereas basic $\mathrm{pH}$ values result in deprotonation and increase of the $\mathrm{C}=\mathrm{N}$ contribution [14]. The N1s structure shown in Fig. 7b is similar to that of DNA (not shown). One can see that the fine structure exhibited by polypyrrole is replaced by a slightly wider and symmetrical peak with the addition of DNA, and this is due to the contribution of a variety of nitrogen-containing groups in the DNA bases. Clark and Barber [32,33] showed that N1s binding energy positions from DNA bases all fall in the 398-399 eV range, hence the tendency to low binding energy side of the polypyrrole substrate and the gradual symmetry of the peak.

High-resolution Cl2p spectra are displayed in Fig. 8 for untreated $\mathrm{PPyCl}, \mathrm{PPyCl}-\mathrm{NaP}$, and $\mathrm{PPyCl}-$ DNA when the DNA adsorption reached $0.29 \mathrm{mg} / \mathrm{m}^{2}$. The Cl2p structure for the freshly synthesized powder (Fig. 8a) is composed of three components centred at $c a .197 .5\left(\mathrm{Cl}_{\mathrm{I}}\right), 199\left(\mathrm{Cl}_{\mathrm{II}}\right)$ and $200.6 \mathrm{eV}$ $\left(\mathrm{Cl}_{\text {III }}\right)$, respectively [3]. The first component, at low BE, is due to the chloride species, the intermediate to a charge transfer between the polypyrrole backbone and the chloride, and the high energy component is due to a covalent $\mathrm{C}-\mathrm{Cl}$ bond (assigned to some surface chemical defects) and/or the existence of chloride species within crystalline zones of polypyrrole [43]. Upon overnight conditioning in phosphate buffer, the $\mathrm{Cl}_{\mathrm{I}} \mathrm{Cl} 2 \mathrm{p}$ component has a much lower relative intensity and the overall $\mathrm{Cl} 2 \mathrm{p}$ peak is noisy. 

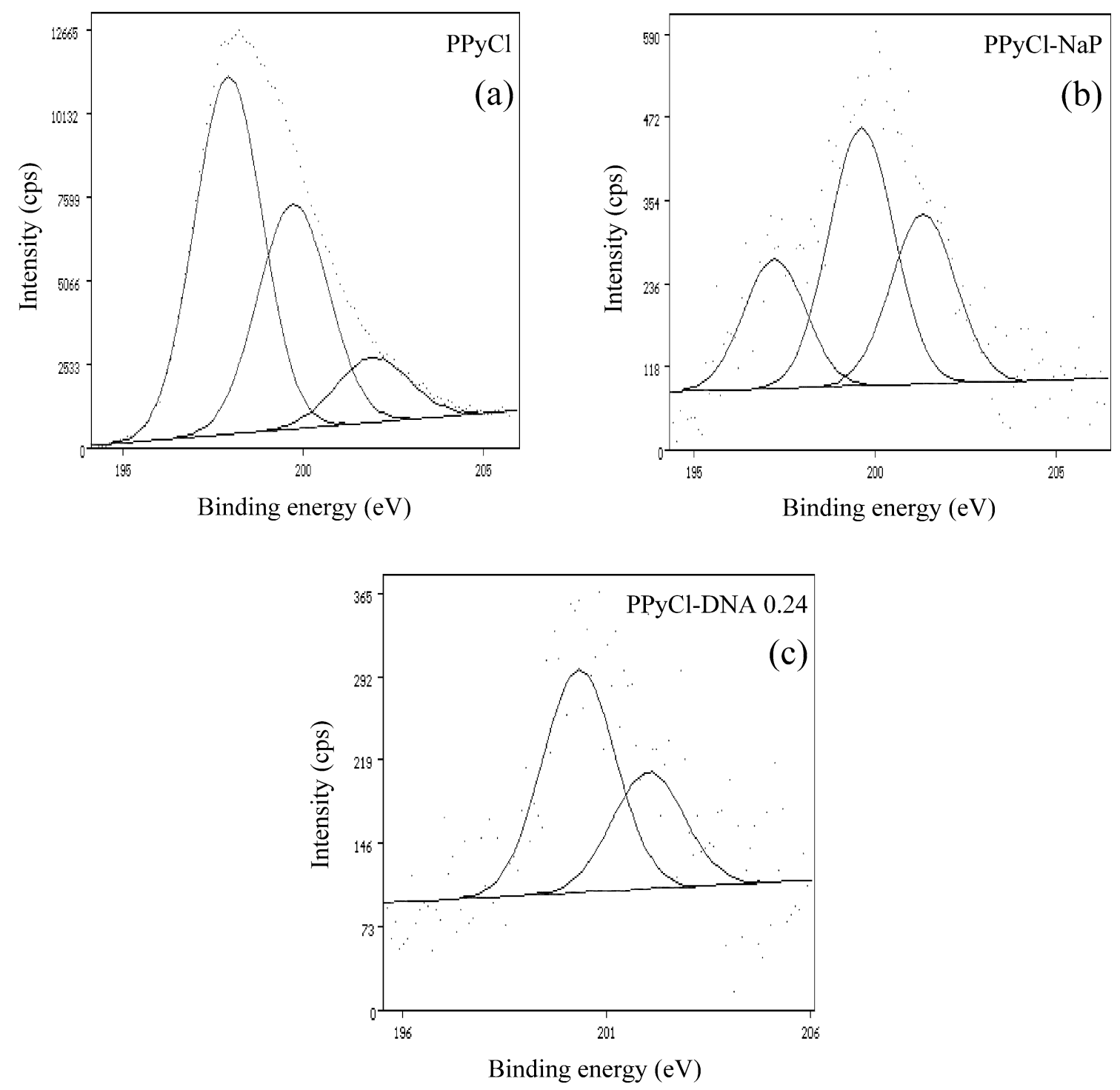

Fig. 8. High resolution Cl2p regions of (a) $\mathrm{PPyCl}$, (b) PPy-NaP, (c) PPy-DNA $\left(0.24 \mathrm{mg} / \mathrm{m}^{2}\right.$ ).

The lower signal/noise ratio confirms the almost disappearance of $\mathrm{Cl} 2 \mathrm{p}$ from the wide scan displayed in Fig. 5b. It should also be emphasized, that the $\mathrm{Cl}_{\text {II }} / \mathrm{Cl}_{\text {III }}$ intensity ratio decreases by comparison to the untreated powder. Buffer treatment thus induces dramatic changes in the relative concentrations of anionic species at the surface of powder particles. This is exacerbated after adsorption of DNA. Indeed, Fig. 8c shows a total loss of the $\mathrm{Cl}_{\mathrm{I}} \mathrm{Cl} 2 \mathrm{p}$ peak corresponding to the loosely bound chloride species. This is a strong supporting evidence of an ion-exchange process that occurs when DNA fragments adsorb. Chloride species must be leached from the extreme surface of the polymer in order to accommodate negatively charged DNA fragments. This result confirms and factually supports the Minehan et al. [13] conclusion, which actually predicted favourable electrostatic interactions between the negatively charged DNA fragments and the positively charged polypyrrole backbone. 
Table 3

Surface chemical composition (in at $\%$ ) of untreated polypyrrole, buffer-treated polypyrrole, and DNA-coated polypyrrole specimens

\begin{tabular}{|c|c|c|c|c|c|c|}
\hline Materials $^{\mathrm{a}}$ & $\mathrm{C}$ & $\mathrm{N}$ & $\mathrm{O}$ & $\mathrm{D}^{\mathrm{b}}$ & $\mathrm{P}$ & $\mathrm{Na}$ \\
\hline $\mathrm{PPyCl}$ & 72.1 & 18.0 & 5.59 & 4.32 & 0.00 & 0.00 \\
\hline PPyCl-NaP & 71.1 & 16.2 & 11.3 & 0.32 & 1.13 & 0.00 \\
\hline PPyCl-DNA-0.07 & 67.4 & 16.4 & 14.0 & 0.16 & 1.81 & 0.25 \\
\hline PPyCl-DNA-0.16 & 65.4 & 16.3 & 15.5 & 0.33 & 1.96 & 0.49 \\
\hline PPyCl-DNA-0.24 & 63.7 & 16.3 & 16.3 & 0.11 & 2.45 & 1.14 \\
\hline PPyCl-DNA-0.29 & 62.5 & 16.0 & 17.6 & 0.16 & 2.40 & 1.28 \\
\hline PPyCl-DNA-0.34 & 60.8 & 16.9 & 18.6 & 0.08 & 2.19 & 1.52 \\
\hline PPyCl-DNA-0.37 & 61.3 & 17.0 & 17.9 & 0.14 & 2.81 & 0.85 \\
\hline PPyCl-DNA-0.39 & 60.1 & 16.7 & 20.0 & 0.17 & 2.34 & 0.67 \\
\hline PPyCl-DNA-0.40 & 61.3 & 16.6 & 18.2 & 0.12 & 2.49 & 1.24 \\
\hline $\mathrm{PPyNO}_{3}$ & 68.9 & 16.0 & 11.1 & 4.01 & 0.00 & 0.00 \\
\hline $\mathrm{PPyNO}_{3}-\mathrm{NaP}$ & 70.1 & 15.2 & 13.3 & 0.09 & 1.28 & 0.00 \\
\hline $\mathrm{PPyNO}_{3}$-DNA-0.164 & 63.7 & 16.8 & 16.8 & 0.00 & 2.35 & 0.50 \\
\hline $\mathrm{PPyNO}_{3}$-DNA-0.25 & 62.8 & 15.3 & 17.8 & 0.00 & 2.91 & 1.23 \\
\hline $\mathrm{PPyNO}_{3}-\mathrm{DNA}-0.375$ & 61.6 & 16.4 & 18.1 & 0.00 & 2.63 & 1.31 \\
\hline $\mathrm{PPyNO}_{3}$-DNA-0.41 & 59.8 & 16.2 & 19.4 & 0.00 & 3.07 & 1.62 \\
\hline $\mathrm{PPyNO}_{3}$-DNA-0.48 & 61.2 & 16.5 & 18.2 & 0.00 & 2.81 & 1.32 \\
\hline $\mathrm{PPyNO}_{3}$-DNA-0.48 & 60.1 & 15.4 & 20.0 & 0.00 & 2.93 & 1.54 \\
\hline DNA & 51.5 & 17.2 & 26.5 & 0.00 & 4.47 & 0.34 \\
\hline
\end{tabular}

${ }^{a}$ The numbers following DNA correspond to the adsorbed amount of DNA in $\mathrm{mg} / \mathrm{m}^{2}$.

${ }^{\mathrm{b}}$ The dopant $\mathrm{D}$ is $\mathrm{Cl}^{-}$for $\mathrm{PPyCl}$ and $\mathrm{NO}_{3}^{-}$for $\mathrm{PPyNO}_{3}$.

The surface composition of all specimens investigated is reported in Table 3. O/N, P/N and N/C atomic ratios calculated from Table 1 are plotted in Fig. 9 versus equilibrium DNA concentration. The isotherms are of high affinity type, especially in the case of $\mathrm{O} / \mathrm{N}$ and $\mathrm{N} / \mathrm{C}$, but reach plateau values for an equilibrium concentration of DNA exceeding $3 \mu \mathrm{g} / \mathrm{ml}$. In the case of P/N, though there is a factor of four between the P/N ratio for buffer-treated polypyrrole and that of DNA, the variation may be hampered by a loss of phosphate anions from the polypyrrole surface, together with chlorides, at the very early stages of DNA adsorption.

The ion-exchange phenomena occurring at the PPy-DNA interface could be analysed in a different way by examining the $\mathrm{Na} / \mathrm{P}$ atomic ratio versus the adsorbed amount of DNA. Figure 10 displays plots of $\mathrm{Na} / \mathrm{P}$ versus DNA adsorption (in $\mathrm{mg} / \mathrm{m}^{2}$ ) for $\mathrm{PPyCl}$ and $\mathrm{PPyNO}_{3}$, at $\mathrm{pH} 7$ and salt concentration of $0.1 \mathrm{M}$. The $\mathrm{Na} / \mathrm{P}$ increases with DNA adsorption and reaches a maximum of $0.7(\mathrm{PPyCl})$ and 0.5 $\left(\mathrm{PPyNO}_{3}\right)$ for an adsorbed amount of $0.3-0.4 \mathrm{mg} / \mathrm{m}^{2}$. These maxima are both lower than the $\mathrm{Na} / \mathrm{P}$ value of 0.8 corresponding to the DNA fibres; this can be analysed as follows:

At low DNA adsorption amounts (typically $<0.2 \mathrm{mg} / \mathrm{m}^{2}$ ), the surface presents a $\mathrm{Na} / \mathrm{P}$ ratio lower than 0.2 , very weak relatively to that of the native DNA. This could be interpreted as a decrease of the $\mathrm{Na}^{+}$concentration at the interface, indicating thus a significant leaching of the $\mathrm{Na}^{+}$ions from the vicinity of DNA phosphates, themselves engaged in electrostatic interactions with the positive charges of PPy. However, the additionally adsorbed DNA (for DNA adsorbed $>0.3 \mathrm{mg} / \mathrm{m}^{2}$ ) carries more $\mathrm{Na}^{+}$ions than the precedent since the $\mathrm{Na} / \mathrm{P}$ ratio continues to increase as DNA adsorbs, and reaches a value limits around 0.5 . This proves that the lately adsorbed phosphates do not compensate for their negative charges 

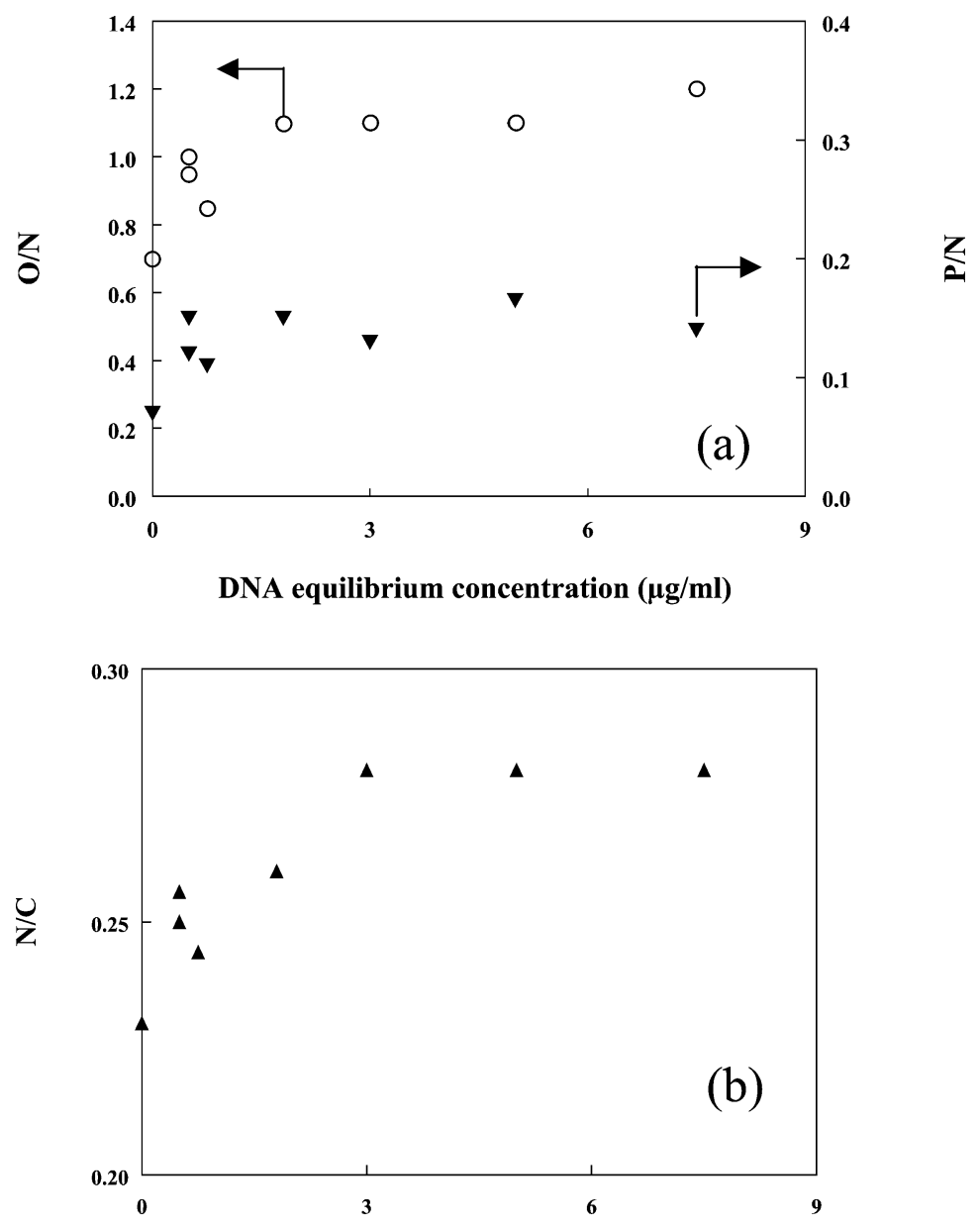

DNA equilibrium concentration $(\mu \mathrm{g} / \mathrm{ml})$

Fig. 9. Adsorption isotherms of DNA onto $\mathrm{PPyCl}$ at $\mathrm{pH} 7$ and $0.1 \mathrm{M}$ ionic strength. The isotherms are constructed by plotting $\mathrm{O} / \mathrm{N}$ and $\mathrm{P} / \mathrm{N}(\mathrm{a})$, and $\mathrm{N} / \mathrm{C}$ (b) atomic ratios versus the equilibrium DNA concentration at $\mathrm{pH} 7$.

by contact with the PPy surface, but with their $\mathrm{Na}^{+}$ions. As a summary, the ion-exchange phenomenon occurring at the PPy-DNA interface takes place in the following way: on the one hand, the surface of PPy expels a fraction of its residual dopant synthesis, and almost all other ions such as phosphates, chlorides, that adsorbed following the ionic exchange with the buffering solution. On the other hand, the DNA releases part of its $\mathrm{Na}^{+}$counter-ions. The ion release operated concomitantly by both the PPy substrate and its adsorbent DNA, would contribute to optimise and strengthen the charge-charge interactions between the two polymers.

We have made similar observations with the adsorption of HSA protein macromolecules on polypyrrole-silica nanocomposites [44] and also with gold nanoparticles immobilised on aminated glass surfaces [45].

From Table 3 it is also possible to examine the respective contributions of DNA and polypyrrole to XPS signals from various systems. It is assumed that for example $\mathrm{C} / \mathrm{N}$ ratios are weighed values of $\mathrm{C} / \mathrm{N}$ 


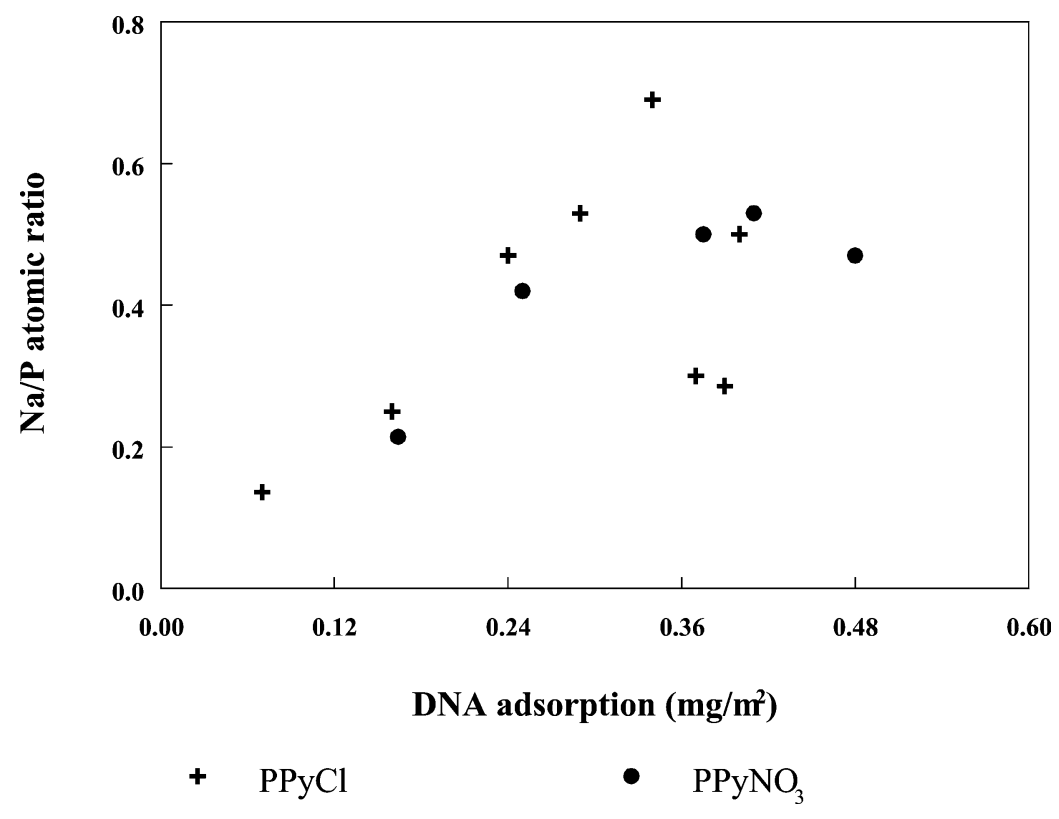

Fig. 10. Plots of $\mathrm{Na} / \mathrm{P}$ atomic ratios versus the amount of adsorbed $\mathrm{DNA}$ onto $\mathrm{PPyCl}$ and $\mathrm{PPyNO}_{3}$.

ratios determined for PPy-NaP and DNA fibres. Therefore, by solving the following equation system one can determine the contribution of each macromolecule to the XPS signal:

$$
\begin{aligned}
& (\mathrm{C} / \mathrm{N})_{\mathrm{PPy}-\mathrm{DNA}}=\alpha(\mathrm{C} / \mathrm{N})_{\mathrm{PPy}}+\beta(\mathrm{C} / \mathrm{N})_{\mathrm{DNA}}, \\
& 1=\alpha+\beta,
\end{aligned}
$$

where $\alpha$ is fraction of PPy and $\beta$, that of DNA. It follows, using different sets of $\mathrm{C} / \mathrm{N}$ values from Table 3, that the contribution of the signal emanating from DNA to the total signal of the polypyrroleDNA system does not exceed $40 \%$. This is a clear indication of an incomplete shielding of the PPy signal by the adsorbed DNA. This further suggests that DNA does not form a continuous and sufficiently thick layer, enabling a complete insulation of the PPy support.

Another way to monitor DNA adsorption, is to determine the static charging effects observable when DNA (an insulating material) adsorbs onto polypyrrole (a conducting material). Static charging is of course an undesirable effect in XPS because it shifts signals from their positions related to the chemical structures by an apparent amount linked to physical artefacts. Static charging must be eliminated physically or determined using the so-called "internal calibration" method in order to obtain the exact positions, which are truly related to the chemical structure of the material under test. Because, we use published chemical shift data, spectral calibration is readily done using either C1s or N1s peaks. This calibration can be used analytically to monitor the change in the apparent peak positions upon DNA adsorption. In our long experience with polypyrrole surface analysis using polychromatic X-ray source, we have systematically observed quasi-zero charging effects with conductive polypyrrole particles. This is also the case for continuous polypyrrole overlayers onto silane-treated silica gel particles [46]. In the present case, an insulating material gradually screens the polypyrrole and the electric current flow is hampered by the presence of a DNA monolayer or patches on top of polypyrrole powder particles. 


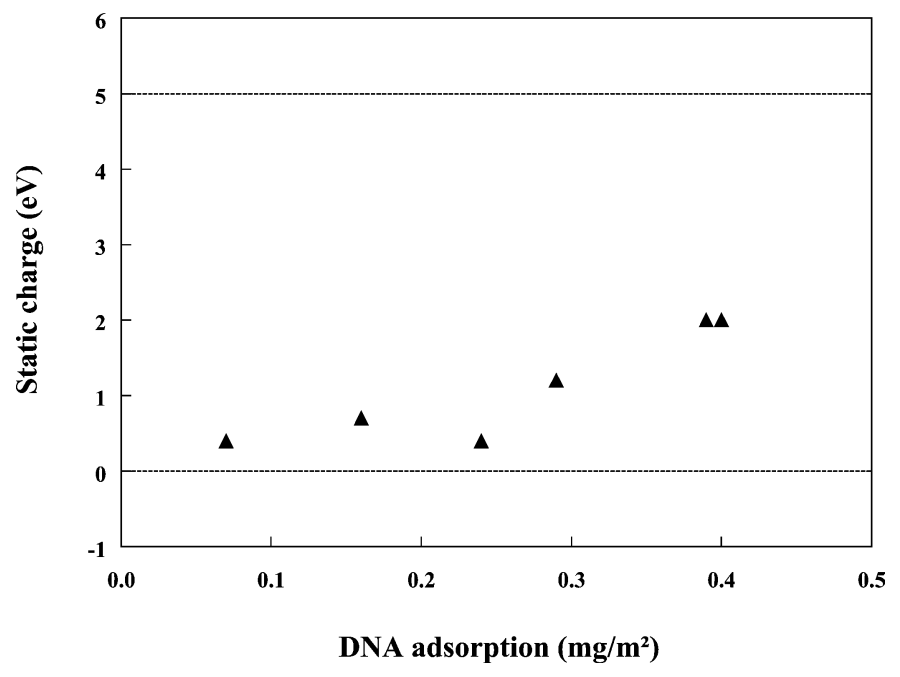

Fig. 11. Effect of DNA adsorption on the static charge of the PPyCl-DNA system. The dashed lines indicate the static charge of the reference materials PPyCl-NaP $(0 \mathrm{eV})$ and DNA fibres $(5 \mathrm{eV})$.

This results in the appearance of a significant static charging, as shown below. Figure 11 shows a plot of static charge (in eV) versus the adsorbed amount of DNA. For reference, the static charges observed with $\mathrm{PPyCl}$ and DNA analysed separately are also indicated ( 0 and $5 \mathrm{eV}$, respectively). Clearly, the static charge does not reach the maximum value observed with DNA fibres, an indication of patchy coatings of DNA onto the underlying polypyrrole.

\section{Conclusion}

Adsorption of DNA fragments onto model polypyrrole powder particles doped with chlorides and nitrates ( $\mathrm{PPyCl}$ and $\mathrm{PPyNO}_{3}$, respectively) has been monitored ex situ, by X-ray photoelectron spectroscopy (XPS). In addition, ion-exchange chromatography permitted to study the replacement of the dopant by the phosphate anions from the buffer at $\mathrm{pH} 7$ and various ionic strengths. Polypyrrole clearly undergoes anion-exchange, however at a maximum of nearly $90 \%$ depending on the initial dopant nature and the ionic strength. The dopants leached from the surface of powders are detected by ion-exchange chromatography, whereas the phosphate uptake by the conditioned powders is clearly visible in XPS spectra. Adsorption isotherms determined by this specific surface analytical technique are of the high affinity type, although the surface elemental compositions of polypyrrole and the underlying buffertreated polymers do not dramatically change. Inspection of the high resolution scans of $\mathrm{C} 1 \mathrm{~s}$ and N1s shows a gradual change in the fine structure of the peaks, which tend to lose the skewness, characteristic of polypyrrole, to get more symmetric peaks resembling those of DNA fibres. A study of the $\mathrm{Na} / \mathrm{P}$ atomic ratio, shows that at the initial stage of adsorption, the negative charges from DNA are counterbalanced by the positive charges from the polypyrrole backbone. Simultaneously, there is a loss of the dopants from the outermost layers of polypyrrole. When adsorption increases, the negative sites of DNA that are away from the DNA-polypyrrole interface are counterbalanced by sodium cations. This is the reason for observing an increasing surface concentration of sodium at relatively high adsorption level.

Finally, taking advantage of the different electrical conductivities of polypyrrole and DNA, it was possible to use analytically the static charging effects observed when DNA adsorption increases. Inter- 
mediate values of static charging resulting in a physical shifts of the peaks in the $0-5 \mathrm{eV}$, is in line with a partial coverage of the polypyrrole surface by DNA, a result deduced from the surface compositions of DNA-coated polypyrrole specimens.

From the above it is concluded that XPS is a powerful tool for investigating interfacial phenomena such as adsorption and adhesion, and can help to reveal and understand the mechanisms underlying such interactions experienced by biomaterials.

\section{Acknowledgements}

The authors would like to thank Mrs C. Connan for her technical assistance with XPS measurements.

\section{References}

[1] (a) T.A. Skotheim, R.L. Elsenbaumer and J.R. Reynolds, eds, Handbook of Conducting Polymers, 2nd edn, Marcel Dekker, New York, 1998. (b) H.S. Nalwa, ed., Handbook of Organic Conductive Molecules and Polymers: Vol. 2. Conductive Polymers: Synthesis and Electrical Properties, Wiley, 1997.

[2] G. Bidan, in: Polymer Films in Sensor Applications, G. Harsányi, ed., Technomic Publishing Co. Inc., Lancaster, 1995, chap. 3, pp. 206-260.

[3] E.T. Kang, K.G. Neoh and K.L. Tan, Adv. Polym. Sci. 106 (1993), 135.

[4] H. Ge and G.G. Wallace, React. Polym. 18 (1992), 133.

[5] M.M. Chehimi, M.-L. Abel, C. Perruchot, M. Delamar, S.F. Lascelles and S.P. Armes, Synthetic Metals 104 (1999), 51.

[6] T.H. Chao and J. March, J. Polym. Sci. Polym. Chem. Ed. 26 (1988), 743.

[7] B. Zinger and L.L. Miller, J. Am. Chem. Soc. 106 (1984), 6861.

[8] H. Chriswanto, PhD thesis, Wollongong University, Wollongong, Australia, 1995.

[9] A.B. Smith and C.J. Knowles, J. Appl. Polym. Sci. 43 (1991), 399.

[10] B. Miksa and S. Slomkowski, Colloid Polym. Sci. 273 (1995), 47.

[11] A. Azioune, K. Pech, B. Saoudi, M.M. Chehimi, G. McCarthy and S.P. Armes, Synth. Met. 102 (1999), 1419.

[12] A. Azioune, M.M. Chehimi, B. Miksa, T. Basinska and S. Slomkowski, Langmuir 18 (2002), 1150.

[13] D.S. Minehan, K.A. Marx and S.K. Tripathy, Macromolecules 27 (1994), 777.

[14] B. Saoudi, N. Jammul, M.-L. Abel, M.M. Chehimi and G. Dodin, Synth. Met. 87 (1997), 97.

[15] B. Saoudi, N. Jammul, M.M. Chehimi, G.P. McCarthy and S.P. Armes, J. Colloid Interface Sci. 192 (1997), 269.

[16] S.P. Armes, in: Intrinsically Conducting Polymers: An Emerging Technology, M. Aldissi, ed., NATO ASI Series, Series E: Applied Sciences, Vol. 246, Kluwer Academic Publishers, Dordrecht, 1993, pp. 35-43.

[17] S.P. Armes in ref. [1a], chap. 17, pp. 423-435.

[18] J. Rodriguez, H.-J. Grande and T.F. Otero, in ref. [1b] (H.S. Nalwa, ed., Handbook of Organic Conductive Molecules and Polymers, Vol. 2, John Wiley \& Sons Ltd, Chichester, 1997, chap. 10, p. 415).

[19] R. Gangopadhyay and A. De, Chem. Mater. 12 (2000), 608.

[20] M.A. Khan, S.P. Armes, C. Perruchot, H. Ouamara, M.M. Chehimi, S.J. Greaves and J.F. Watts, Langmuir 16 (2000), 4171.

[21] M. Omastová, J. Pavlinec, J. Pionteck, F. Simon and S. Košina, Polymer 39 (1998), 6559.

[22] P.J. Tarcha, D. Misun, D. Finley, M. Wong and J.J. Donovan, in: Polymer Latexes: Preparation, Characterization and Application, E.S. Daniels, E.D. Sudol and M.S. El-Aassar, eds, ACS Symp. Ser. 492; American Chemical Society, Washington, DC, 1992, chap. 22.

[23] M.R. Pope, S.P. Armes and P. Tarcha, Bioconjugate Chem. 7 (1996), 436.

[24] B. Saoudi, C. Despas, N. Jammul, M.M. Chehimi, M. Delamar, J. Bessière and A. Walcarius, Sensors Act. B. Chem. 62 (2000), 35 .

[25] D. Briggs and M.P. Seah, eds, Practical Surface Analysis, 2nd edn, Vol. 1, Auger and X-Ray Photoelectron Spectroscopy, John Wiley, Chichester, 1990.

[26] G. Beamson and D. Briggs, eds, High Resolution XPS of Organic Polymers. The Scienta ESCA300 Database, John Wiley, Chichester, 1992.

[27] F. Garbassi, M. Morra and E. Occhiello, eds, Polymer Surfaces. From Physics to Technology, John Wiley, Chichester, 1994, pp. 92-113. 
[28] B. Ratner and D. Castner, in: Surface Analysis. The Principal Techniques, J.C. Vickerman, ed., John Wiley, Chichester, 1997, chap. 3, pp. 43-98.

[29] M.M. Millard, in: Protein-Metal Interactions, M. Friedman, ed., Plenum Press, New York, 1974, pp. 589-619.

[30] M.M. Millard, Contemp. Top. Anal. Clin. Chem., series 3 (1978), 1.

[31] R.W. Paynter and B.D. Ratner, in: Surface and Interfacial Aspects of Biomedical Polymers, Vol. 2, J.D. Andrade, ed., Plenum Press, New York, 1985, pp. 189-216.

[32] M. Barber and D.T. Clark, J. Chem. Soc., Chem. Commun. (1970), 23.

[33] M. Barber and D.T. Clark, J. Chem. Soc., Chem. Commun. (1970), 24.

[34] A. Imamura, H. Fujita and C. Nagata, J. Am. Chem. Soc. 94 (1972), 6287.

[35] R. Rein, A. Hartman and S. Nir, Israel J. Chem. 10 (1972), 93.

[36] M.P. Klein and L.N. Kramer, Chem. Phys. Letters 8 (1971), 183.

[37] M.M. Millard and M.S. Masri, Anal. Chem. 46 (1974), 1820.

[38] B.D. Ratner, T.A. Horbett, D. Shuttleworth and H.R. Thomas, J. Colloid Interface Sci. 83 (1981), 630.

[39] A.J. Leavitt, L.A. Wenzler, J.M. Williams and T.P. Beebe, J. Phys. Chem. 98 (1994), 8742.

[40] Y.-D. Zhao, D.-W. Pang, S. Hu, Z.-L. Wang, J.-K. Cheng, Y.-P. Qi, H.-P. Dai, B.-W. Mao, Z.-Q. Tian, J. Luo and Z.-H. Lin, Analytica Chim. Acta 388 (1999), 93.

[41] G. Polzonetti, G. Iucci, A. Frontini, G. Infante, C. Furlani, L. Avigliano, D. Del Principe, G. Palumbo and N. Rosato, Biomaterials 21 (2000), 1531.

[42] L.R. Snyder and J.J. Kirkland, Introduction to Modern Liquid Chromatography, 2nd edn, Wiley, New York, 1979.

[43] M.-L. Abel, PhD Thesis, Université Paris 7-Denis Diderot, Paris, France, 1996, p. 130.

[44] A. Azioune, A. Ben Slimane, L. Ait Hamou, A. Pleuvy, M.M. Chehimi, C. Perruchot and S.P. Armes, Langmuir 20 (2004), 3350.

[45] O. Seitz, M.M. Chehimi, E. Cabet-Deliry, S. Truong, N. Felidj, C. Perruchot, S.J. Greaves and J.F. Watts, Colloids Surf. A. Phys. 219 (2003), 225.

[46] C. Perruchot, M.M. Chehimi, M. Delamar and F. Fievet, Surf. Interface Anal. 26 (1998), 689. 


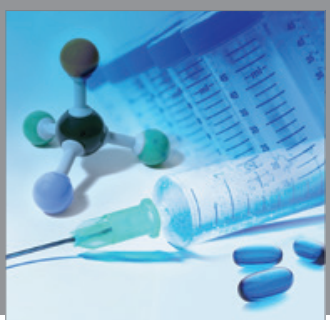

International Journal of

Medicinal Chemistry

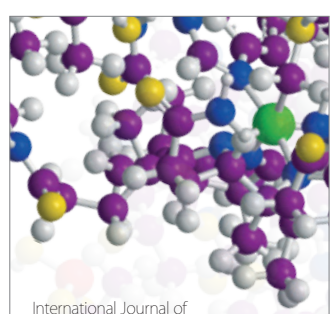

Carbohydrate Chemistry

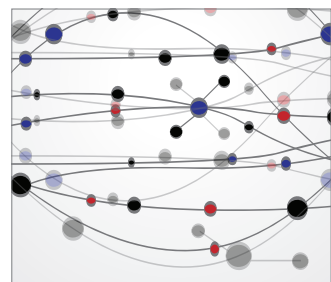

The Scientific World Journal
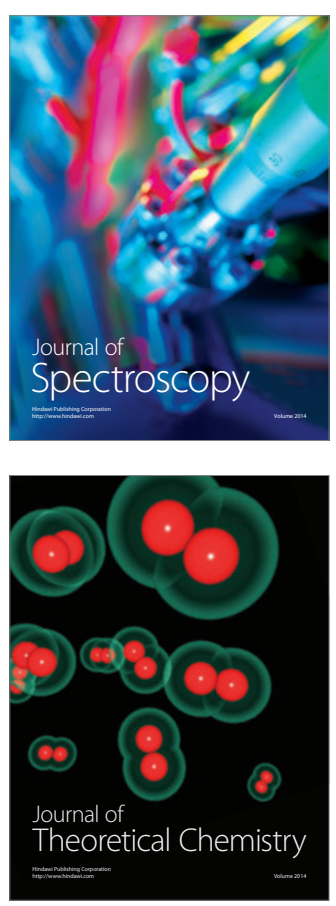
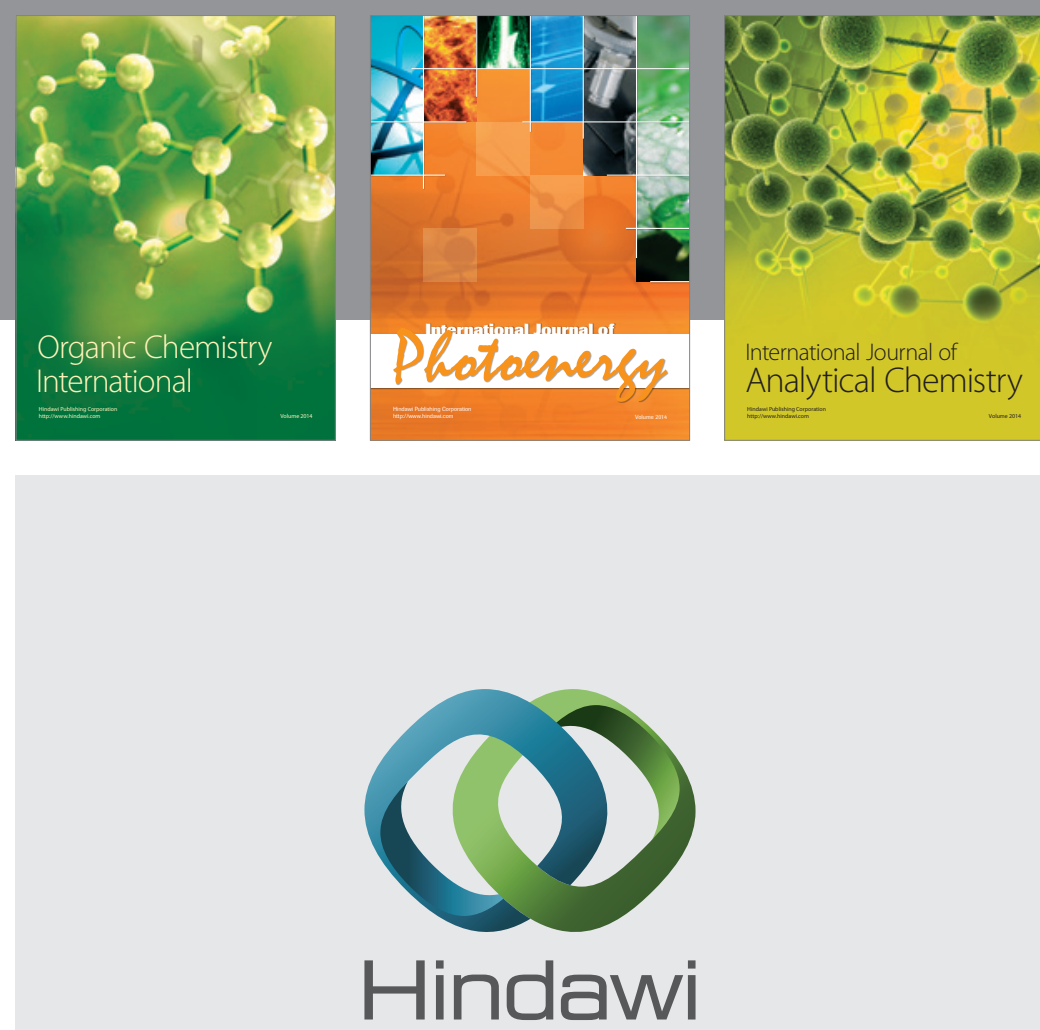

Submit your manuscripts at

http://www.hindawi.com
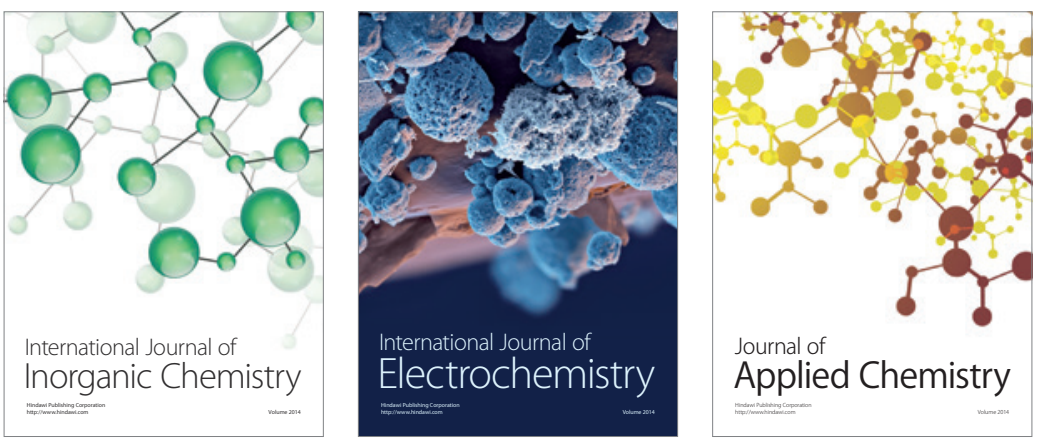

Journal of

Applied Chemistry
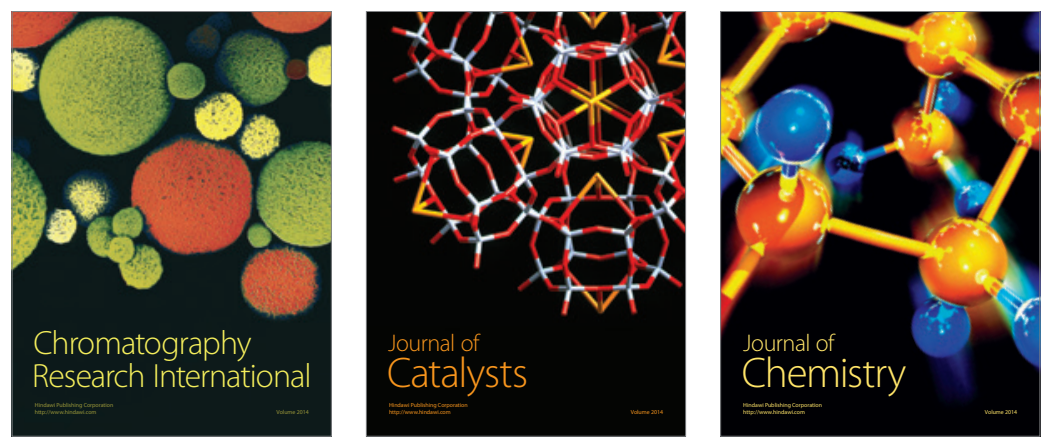
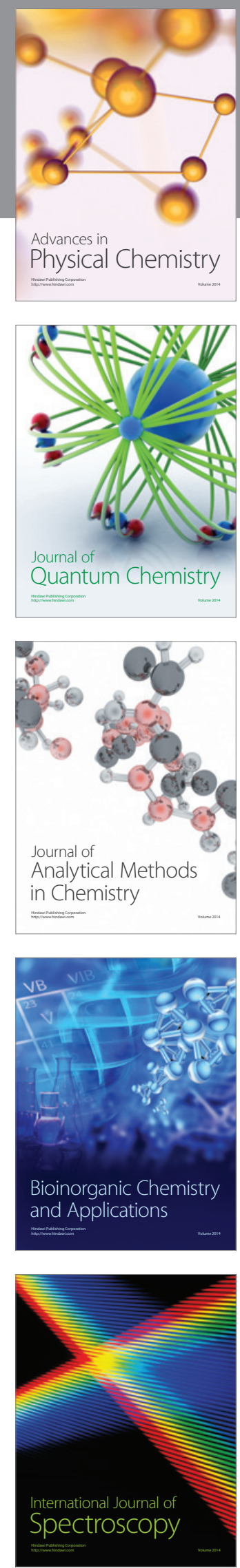